Meta

Journal des traducteurs

Translators' Journal

\title{
Shortcuts, Strategies and General Patterns in a Process Study of Nine Professionals
}

\section{Paula Asadi et Candace Séguinot}

Volume 50, numéro 2, avril 2005

Processus et cheminements en traduction et interprétation Processes and Pathways in Translation and Interpretation

URI : https://id.erudit.org/iderudit/010998ar

DOI : https://doi.org/10.7202/010998ar

Aller au sommaire du numéro

Éditeur(s)

Les Presses de l'Université de Montréal

ISSN

0026-0452 (imprimé)

1492-1421 (numérique)

Découvrir la revue

Citer cet article

Asadi, P. \& Séguinot, C. (2005). Shortcuts, Strategies and General Patterns in a Process Study of Nine Professionals. Meta, 50(2), 522-547.

https://doi.org/10.7202/010998ar
Résumé de l'article

Jusqu'à maintenant, les études qui ont porté sur le processus de traduction ont toujours dû faire face à la difficulté de reproduire les conditions de travail réelles des traducteurs professionnels. Même la définition de ce qu'on entend par professionnalisme a pu varier. Notre étude, en revanche, s'est donné pour objectif de ne considérer que les stratégies employées au sein d'un groupe assez nombreux de professionnels travaillant tous dans un même lieu. Ce groupe était composé de neuf traducteurs travaillant pour une compagnie pharmaceutique à des traductions requérant des connaissances et de l'expérience dans ce domaine de spécialisation. Nous pensions en effet que s'il existait des stratégies propres à tous les traducteurs appartenant à un même environnement institutionnel, celles-ci apparaîtraient soit dans le processus de la traduction capté par vidéo, soit dans les remarques qu'ils pouvaient se faire tout haut en travaillant (les TAP's) ou dans les entretiens à la fin de chaque séance d'enregistrement.
Ce document est protégé par la loi sur le droit d'auteur. L'utilisation des services d’Érudit (y compris la reproduction) est assujettie à sa politique d'utilisation que vous pouvez consulter en ligne.

https://apropos.erudit.org/fr/usagers/politique-dutilisation/ 


\title{
Shortcuts, Strategies and General Patterns in a Process Study of Nine Professionals
}

\author{
PAULA ASADI \\ York University, Toronto, Canada \\ paula_asadi@hotmail.com
}

CANDACE SÉGUINOT

York University, Toronto, Canada

seguinot@glendon.yorku.ca

\begin{abstract}
RÉSUMÉ
Jusqu'à maintenant, les études qui ont porté sur le processus de traduction ont toujours dû faire face à la difficulté de reproduire les conditions de travail réelles des traducteurs professionnels. Même la définition de ce qu'on entend par professionnalisme a pu varier. Notre étude, en revanche, s'est donné pour objectif de ne considérer que les stratégies employées au sein d'un groupe assez nombreux de professionnels travaillant tous dans un même lieu. Ce groupe était composé de neuf traducteurs travaillant pour une compagnie pharmaceutique à des traductions requérant des connaissances et de l'expérience dans ce domaine de spécialisation. Nous pensions en effet que s'il existait des stratégies propres à tous les traducteurs appartenant à un même environnement institutionnel, celles-ci apparaîtraient soit dans le processus de la traduction capté par vidéo, soit dans les remarques qu'ils pouvaient se faire tout haut en travaillant (les TAP's) ou dans les entretiens à la fin de chaque séance d'enregistrement.
\end{abstract}

\begin{abstract}
To date, most process studies have had to get around the problem of duplicating the working environment of professional translators. In fact, the definition of professionalism itself has varied. This study was designed specifically to focus on the strategies of a large group of professionals all from the same workplace. The research involved nine translators in the linguistics department of one pharmaceutical company working on the kind of text that required their specialized experience. It was hoped that if there were experience-related or text-specific strategies shared by translators in the same institutional environment, they would surface either in the record of the translating process or in the think-aloud or retrospective protocols.
\end{abstract}

\section{MOTS-CLÉS/KEYWORDS}

translation process, think-aloud protocol, professional translator, observation of translation

\section{Introduction}

The best way to find out how professionals translate seems to be to study the experts in action. However one of the challenges of studying professionals is that many of their processes are automatized with practice and repetition and therefore cannot be verbalized. According to Ericsson and Simon (1980, 1984) subjects can only verbalize thoughts in short-term memory and automated skills may bypass this short-term memory. In addition to this, Langacker (1987:57) states that "automatization is a matter of degree. Every use of a structure has a positive impact on its degree of 
entrenchment" and "text-units become variably entrenched depending on the frequency of their occurrence." In this way, expert translators develop shortcuts over time that help to speed up the process (Jääskeläinen: 1989, 95 and TirkkonenCondit: 1989, 78).

In a complex task such as translation, short-term memory is filtered in from sensory memory and given attention, but this memory is easily interrupted or lost. Chunking information together is one way that professionals tend to maximize the amount of information that can be held in the short-term memory at once. Through practice and repetition, these chunks of information are transferred to long-term memory for future recall. Learning more about the processes involved in translation will help determine which processes require training and which processes require repetition to become automated.

To date, most of the process studies that speak of observing the translating of professionals either have used one or two professionals or have defined professionalism in a way that means someone who has done translations and has been paid for them, or teachers as opposed to students, or advanced students of translation versus beginners. This study was designed specifically to focus on the strategies of a larger group of professionals all from the same workplace. The research involved nine translators in the linguistics department of a pharmaceutical company. Two, subjects number one and two, translated from French to English. All the others were working from English into French. The research was carried out on the company premises using a text related to their area of expertise.

\subsection{Methodology}

The experimental set-up was made to reflect the subject's natural working environment, including access to their usual reference materials. They were asked not to go to the cancer site from which both versions of the text were taken. In order to record a real-time account of the translation process, Camtasia Studio, a screen video recorder, was installed on the computers to provide a timed account of every action which took place on the screen during the production. In addition to recording the production of the translation, including all searches of electronic resources, the program records cursor movements and clicks. Camtasia Studio works in the background and is invisible to the subject. It does not affect the translator's natural working environment, an important factor in maintaining the ecological validity of the data.

In addition, both concurrent and retrospective think-aloud protocols were collected. Each subject wore a microphone during the session and verbalizations were recorded as part of the video of the translation production. The subjects were asked to think aloud as much as possible, saying everything that came to mind during the production, without trying to explain these verbalizations in any structured way. They were told that pauses were allowed as much as necessary. A demonstration or practice session was used to familiarize each subject with the concept of thinking aloud. The concurrent reports were later transcribed with timings from the videos. The researcher also interviewed each subject after the translation session. These reports, together with the keystroke data from the videos, provide insight into the decisions, pauses and editing that take place during the translation process. 
Given that the goal of professional translators is to produce a quality product using the least amount of effort and time, it is natural to assume they develop strategies to cope with gaps in knowledge or memory capacity and shortcuts to save time. The purpose of this research was to look for these strategies.

\section{Data and experimental design}

The translators were asked to translate for 20 minutes as they normally would. The researcher gave a demonstration of thinking aloud while translating and demonstrated how the on-screen production would be recorded. All the subjects' questions were answered. The source texts were parallel pages from the Canadian Cancer Society's public website. The content and terminology of the source texts represent routine tasks for this group of translators.

\subsection{Analysing data}

The think-aloud protocols were transcribed and interwoven with the production of the translation. The sample excerpt that follows shows the style format used. The bold text indicates the actual text typed on-screen. Edits (immediate revisions) are indicated by a single strikethrough line. Revisions are indicated by a double strikethrough line. Verbalizations are inserted in italics. Timings are indicated in parentheses and the researcher's comments, including an explanation of dictionary look-ups, are indicated in square brackets. Text boxes at the right of the excerpt point to general patterns, which will be discussed in later sections. Final production as it appeared at the end of the 20-minute experiment follows each excerpt.

[Excerpt from the transcription of Subject 2]

(05:30) In the past, paxlitaxel (Taxol) was usually administered for a period of 24 hours to patients with ovarian cancer until a clinical trial conducted with Canadian and European patients $(06: 22)$... showed... showed that faire la prevue [Termium look-up: FAIRE LA PREUVE] [Termium look-up: FAIRE PREUVE] demonstrate... (06:49) ...check this...Robert... [Hardcopy Le Robert look-up] faire la prevue... [Replaces "showed" with "proved"] show troved (07:40) sûr is safe it was just as style: safe and effective to do the treatment in only three hours. (08:13) Hmm...ya [cut "to patients with ovarian cancer" and pasted it after "usually administered"] (08:30) ...better... (08:37) Ok...period...[sigh]... [Replaces "for" with "over"] for over [inserts "a 24-hour" after "period of" and deletes " 24 hours"] a 24 -hour 24 hours (08:54) period

\section{Final production:}

In the past, paxlitaxel (Taxol) was usually administered to patients with ovarian cancer over a 24-hour period, until a clinical trial conducted with Canadian and European patients proved that it was just as safe and effective to carry out the treatment in only three hours.

\subsubsection{Text segments as a framework}

In a previous investigation of the translation unit, Séguinot (1999:90) points out that "experts say that they translate sentence by sentence, or that in most cases this is what competent translators do." But they don't. In this study, the translators were 
more likely to work on smaller segments at the propositional or even at the phrase level. The psychological validity of the unit is seen in the instances, discussed later, where three translators marked a segment of text they had finished dealing with with a period, revealing that they were working at the propositional level, though the sentence had not been completed. Séguinot (1999:87) explains, "as completeness of meaning does not coincide with typographical sentences, the definition of a sentence as a complete thought is simply inaccurate." Although there is some evidence to show that sentences often act as "operational units" (Séguinot 1999:93) for professionals performing routine types of translation, what is clear from the process study of these nine professionals is that segment length is variable

In this study, a segment of text is defined as text typed at a steady rate without any breaks or pauses. The end of a segment is marked by punctuation, rereading, reading ahead, or an interruption in the text being produced. Interruptions may include environmental/external influences, typing errors that cause a break in the flow of production, or a change in the translator's thought process (indicated by verbalizations and/or by a shift from the text segment being produced to another action). Séguinot (1999:90) questions whether there is empirical proof to support the assumption that the sentence is a translation unit from an operation point of view, and whether it is justified to recommend this level to translation students. On the one hand, the present research suggests that professionals are more likely to translate text segments at the propositional level rather than the sentence level, while at the same time the data provides evidence that translating larger units is a more successful strategy.

\subsubsection{Shortcuts and Strategies}

Translators tend to develop their own time-saving strategies with experience, but rarely in collaboration with other translators. In a previous study, Séguinot (1989:40) noted:

...it seems logical that the successful translator would develop time-saving strategies. Among the strategies discovered in this study was the tendency to take advantage of physical interruptions to make changes, the tendency to continue translating for as long as possible and put off meaning changes until later, and a technique for dealing with the limitations on short-term memory.

From this data we can hypothesize which of the shortcuts are individual, specialtyrelated, or shortcuts that are useful to a wider group of professionals, developed to cope with translation-specific problems.

One of the problems of studying a small subject population is that individual's strategies are attributed to all translators, and all text-types. What seems clear from this data is that translation styles are not clear-cut. Rather, it seemed possible to discern patterns and then deal with groupings of patterns.

A pattern was defined as a particular shortcut or strategy used by three or more translators. Several patterns were observed in this study, each of which will be discussed later.As an example of how an emerging pattern was detected, here is a section of a transcript followed by an explanation: 
Excerpt from the transcription of Subject 3:

(00:00) [Initial orientation phase begins] Je commence par mon premier jet (00:11)

Alors... Essais cliniques clés (00:22) Des exemples d'essaies cliniques... fait une lecture préliminaire (00:40) Ok. Des essaies cliniques...est-ce que c'est technique ou est-ce que ça l'est pas? (00:50) Non, c'est pas très technique. (01:00) Ok. [Drafting phase begins] (S3)

\section{Final production: Essais cliniques clés}

Gloss: [Initial orientation phase begins] I am starting with my first draft. (00:11) Ok...Essais cliniques clés (00:22) Examples of clinical trials...doing a preliminary reading (00:40) Ok. Clinical trials... is it technical or not? (00:50) No, it's not very technical. (01:00) Ok. [Drafting phase begins]

This subject starts by typing the title and then scans the text, taking bearings and evaluating the level of difficulty. It is the first sign that this subject takes a prospective approach to the task; planning and evaluating the task at the text-level. After the initial phase, the drafting phase begins. In the drafting phase, we are able to observe what Jakobsen (2002:193) refers to as "online" revision. By studying the process, we see the balance of production and interruptions that constitute the drafting phase, as well as the impact of technology on the production.

\subsection{Analysing general patterns}

One general pattern that emerged was that translators either translated a segment of text mentally and then typed it, or they translated as they were reading the text. These two styles are referred to here as Prospective Thinking and Translating Onscreen. More evidence of monitoring and online revision were also observed in this study. In addition to these general patterns, there is evidence of internal searching to trigger language, and in three instances, there are false starts caused by interference from automatized connections between previously translated phrases in the text. Lastly, three translators typed a period after translating a proposition, mistaking the unit for a full sentence. These general patterns are discussed below with examples from the transcribed productions.

\subsubsection{Two production styles}

These nine professionals appear to use one of two cognitive approaches to produce a translation. The factors associated with each style are shown in the illustration. The first style involves prospective thinking, and it is reminiscent of the style used in precomputer translation. Historically, professionals using a typewriter or Dictaphone were forced to translate first mentally or orally, taking in large chunks of text and reading ahead for comprehension before beginning to type. Four of the subjects in this study followed this approach, reading large segments of the text and making most of their translation decisions and changes mentally before typing. 


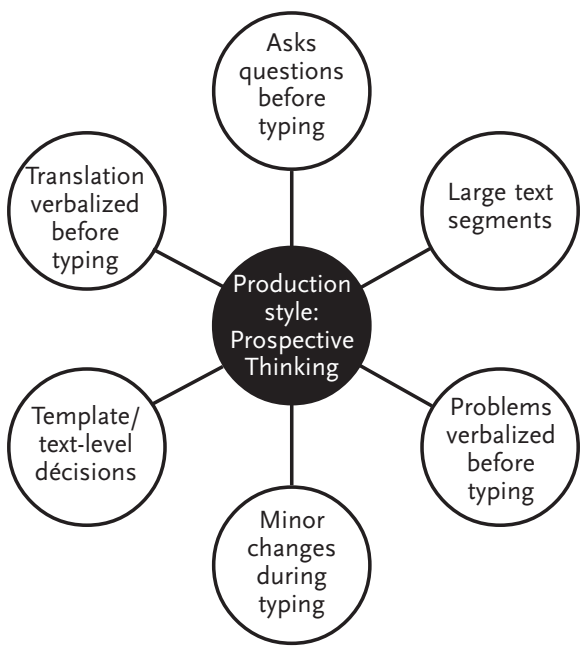

FIGURE 1

A model of signs of a Prospective Thinking production style

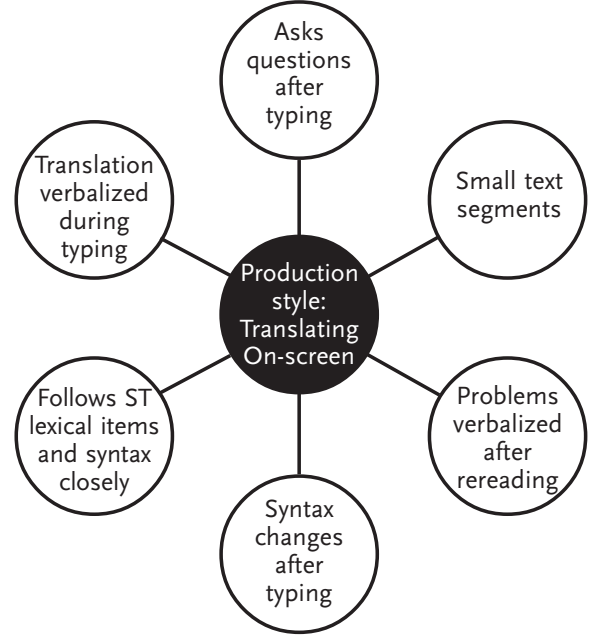

FIGURE 2

A model of signs of a Translating On-screen production style

The excerpt below shows the production of two sentence-level segments of text which are first constructed mentally and then typed:

Excerpt from the transcription of Subject 3:

(03:57) Alors...(04:00) Vingt-quatre heures, wow, ok. Euh...des patients canadiennes et européennes...bien plus moins du temps...ptus confortable et... bon...très simple, ok. (04:22) Auterfoierres Autrefois... le médicament, le paclitaxel euh, c'est moche... [Replaces "le médicament" with "Taxol"] te médieament Taxol [types over "le paclitaxel" with the next part of the phrase] le paclitaxel, était administré aux femmes atteintes de cancer des ovaires sur une période de 24 heures. (04:55) Donc, avant de faisait ça maintenant depuis...hmm...Toutefois, un essai clinique (05:11) Un essai Thinking clinique...dans lequel particip ont participé des patientes Européennes et (05:27) Voyons, minuscule et... [Replaces capital "E" with lowercase "e" in "européennes"] Ee canadiennes ont a révélé que le médicament éai [inserts "t" into "était"] t plus efficace et tout aussi (05:50) C'est drôle... qui soit plus efficace moi j’aurais pensé que ce sera moins...plus aussi efficace mais, tout aussi...mais moins euh...mais plus sécuritaire plutôt que plus efficace et tout aussi sécuritaire...enfin... mais bon, est-ce que je mets plus sécuritaire ou est-ce que je mets sût dans un texte générale, enfin j'écris sécuritaire et vérifierai après sécuritaire lorsqu'il était administré pendant 8 heure [replaces " 8 " with " 3 "] 83 s (06:34) Trois heures...

Final production:

Autrefois, Taxol, le paclitaxel, était administré aux femmes atteintes de cancer des ovaires sur une période de 24 heures. Toutefois, un essai clinique dans lequel ont participé des patientes européennes et canadiennes a révélé que le médicament était plus efficace et tout aussi sécuritaire lorsqu'il était administré pendant 3 heures. 
Gloss: (03:57) Ok...(04:00) Twenty-four hours, wow, ok. Um...Canadian and European patients...much less time...more comfortable and...

good...very easy, ok. Auterfoierres (04:22) In the past...le médicament, le paclitaxel uh, that's no good... [Replaces "le médicament" with "Taxol"] te médieament Taxol [types over "le paclitaxel" with the next part of the phrase] le paclitaxel, était administré aux femmes atteintes de cancer des ovaires sur une période de 24 heures. (04:55) So, before doing that now since...hmm ... Toutefois, un essai clinique (05:11) A clinical trial...dans lequel particip ont participé des patientes Européennes et (05:27) Come on, lowercase and... [replaces capital "E" with lowercase "e" in "européennes"] Ee canadiennes ont a révélé que le médicament éai [inserts " $t$ " into "était"] t plus efficace et tout aussi (05:50) That's funny... that are more effective I would have thought this would be less... as effective but, also...but less uh...but safer rather that more effective and just as safe... anyway...but ok, do I put more eficacious or do I put in a general text, anyway I'm putting safe and I will check later sécuritaire lorsqu'il était administré pendant 8 heure [replaces "8" with " 3 "] 83 s (06:34) Three hours...

In the first sentence, only two changes are made during the typing, including one spelling correction and one omission at the beginning of the sentence. Next, 17 words are translated at a steady rhythm without changes. The sentence restructuring and lexical choices are made mentally and the whole sentence is translated together. The think-aloud data shows that the translator read and translated both sentences mentally or aloud over a period of 22 seconds before typing began. Since this subject has many years of experience in pharmaceutical translation and is specialized in the area of oncology, it is possible that phrases such as "women with ovarian cancer" are automatized and stored in long-term memory, leaving room in the short-term memory for a longer text segment. This would also explain why the subject does not translate the chunk aloud, while the more difficult construction, "bien plus moins du temps," which appears in the subsequent sentence, is verbalized. Later on there is more evidence of prospective thinking when the subject considers the audience and the nature of the text while deciding between technical and general variants.

Prospective thinkers did better than on-screen thinkers with problematic text segments. For example, the English, "These trials are completed and are no longer accepting patients" uses the word 'patients'where the collocation with 'trials' would normally be 'subjects.'

\begin{tabular}{l|l|} 
[Excerpt from the transcription of Subject 3] & $\begin{array}{l}\text { Editing and } \\
\text { improving } \\
\text { on the } \\
\text { source text }\end{array}$ \\
VeRemarque: Les essais cliniques en question sont terminés et ne \\
recrutent plus de patietnsnts (03:29) de sujets...faut traiter patients...
\end{tabular} (03:36) De toute façon les sujets en oncologie sont tous des patients

Gloss: $\forall$ Remarque: Les essais cliniques en question sont terminés et ne recrutent plus de patietnsnts (03:29) subjects... must treat patients...(03:36) In any case, oncology subjects are all patients

Prospective thinking involves making text-level decisions and planning ahead. There is evidence of monitoring going on at a text level in two of the subjects in this group. These "template" decisions affect the whole translation, such as the question posed in the following excerpt that demonstrates the translator is monitoring for consistency: 
[Excerpt from the transcription of Subject 3]

Plus récemment, un essai clinique (06:49) Est-ce que je mets essats cliniques partout ou est-ce que je l'alterne avec études cliniques de temps en temps? Ça fait lourd...je l'y penserai après. Text-level Monitoring for

consistency

Gloss: Plus récemment, un essai clinique (06:49) Should I put "clinical trials" all the time or should I alternate it with "clinical studies" now and then? It's tedious...I'll think about it later

One of the prospective thinkers switches strategies after translating the first paragraph in order to gain a more global understanding of the text. The subject interrupts the flow of translation and decides to translate all of the paragraph headings before proceeding. This finding supports Séguinot's (1989:34) observation that "rather than proceeding by units, what seems to happen is that the translator switches strategies depending on the interplay between memory constraints and the difficulties encountered in the source text. There is also evidence of a critical awareness or monitoring of the translation task being performed."

[Excerpt from the transcription of Subject 4]

(09:50) Je pense que je vais traduire les autres titres comme ça ça va me donner une bonne idée euh, du but euh, du texte améliorer [starts typing] donc améliorer, le traitement $d u$ cancer $d u$ côlon Améliorer le traitement du cancer du côlon (10:08) Après ça je vais regarder les mots dans la table des matières si c'est la façon qu'on le met parce que un peu comme, euh... (10:20) [Starts typing] Augmentation du taux de Augmentation du taux de gu ...oh, le mot "guérison"... pour le cancer [typing] érison c'est un mot qui est euh, un peu, un peu lourd-je vais regarder dans Gladstone cure mais le mot en anglais est fort habituellement on parle de remissions dans les textes anglais pour ne pas donner trop d'espoir aux patients mais cure c'est bien euh, euh cure guérir, oui, guérison donc c'est bien guérison le mot est fort mais on va utiliser le mot aussi en français augmentation du taux de guérison [starts typing again] du cancer du cancer du poumon du Text-level decision: Switching strategies poumon ...euh, oui, ça aussi je pense qu'on dit cancer du poumon et non the subject returns to her previous strategy, translating the text from left to right. pas [mumbles] plusieurs (11:17) Bon, [rereading] améliorer - c'est vrai qu'on dit cancer de sein [mumbles] jamais cancer des seins. Śai mon réponse améliorer [typing] améliorer le traitement le traitement du cancer du candcer $d u$ sein du sein...donc un peu...dadada, je vois en plus ou le texte veux en venir

Gloss: (09:50) I think that I will translation the other titles like this - this will give me a good idea of the object of the the text improve [starts typing] so, improve the treatment of colon cancer Améliorer le traitement du cancer du côlon (10:08) After that I will look at the words in the table of contents if this is the way we put this because a little like, uh...(10:20) [Starts typing] Increase in the rate of Augmentation du taux de gu ...oh, the word "healing" ... for cancer [typing] érison this is a word that is, uh, a little, a little strong - I will look in Gladstone "cure" but the word in English is strong usually we speak of remissions in English texts so as not to give too much hope to the patients but "cure" is good uh, cure "guérir," yes, cure so it's definitely cure the word is strong but we will also use the word in French increase in the cure rate [starts typing again] of lung cancer du cancer du poumon ...uh, yes, that too I think we say lung cancer and not [mumbles] lung cancers (11:17) Good, [rereading] Improve - It's true we say breast cancer [mumbles] never cancer of the breasts... I have my answer Improve [typing] améliorer the treatment le traitement of breast cancer du candcer du sein...so a little...dadada, I see more where the text is going 
The second production style, on-screen translation, was used by five of the subjects. They spent less time on planning, tackled shorter text segments, and took advantage of the word processing environment to facilitate the process.

Excerpt from the transcription of Subject 1

In the past, (07:57) In the past paclitaxel (Taxol) was usually administereded for a period of 24 hours for a period period of 24 hours 24-hour period actually for a 24-hour period that sounds a little more English...(08:24) Durant une période... to patients with ovarinaan cancer [inserted after "administered"], until a (08:54) Until a... etintinica ooh...trial conducted with patie a clinical trial conducting in... in, in... in p-Canadian wha-...Canadian and European...patients...... and European patients proved (09:23) Proved, or...faire preuve maybe that would be like, demonstrated, or...faire prevue... let's look that up...[Termium FAIRE PREUVE] (09:23) Proved, or...faire preuve maybe that would be like, demonstrated, or...faire prevue...let's look that up...(09:37) Uh...demonstrated...uh, ya, I'd like to say that proved demonstrated that (09:48) Demonstrated...that...it...was... just as safe and effective it was just as safe and effective to perof per (10:04) To oh "effectuer" is one of those words... [Termium EFFECTUER] (10:10) "Effectuer" is like...perform but it can also be...oh, carried out, that might be a good solution...(10:18) Uh... where am I, I am now looking just on my sheet to see where I am and I...(10:30) "Effectuer"...carry out the treatment per carry out the trat reatment (10:39) Ya, that sounds alright, the treatment in 3 hours Production style: Translating On-screen revision: Following the source text syntax (10:48) In...three hours?.. That doesn't make sense because... after three hours, maybe?... in three hours...like...... [moves the " 3 " to the next line while thinking aloud] (11:09) Ok hang on.... [rereading paragraph] administré durant une période de 24 heures... for a period... of 24 hours or...hmm, alright, I will leave it as such...

\section{Final production:}

In the past, paclitaxel (Taxol) was usually administered to patients with ovarian cancer for a 24-hour period, until a clinical trial conducted in Canadian and European patients demonstrated that it was just as safe and effective to carry out the treatment in 3 hours.

Instead of working with the largest segment of text permitted by short-term memory, the subjects above primarily worked on shorter text segments, propositions, and phrases closer to Vinay \& Darbelnet's (1958:16) definition of a translation unit. As each segment of the sentence was translated, the subjects made changes in lexical choice and syntax to reflect their growing comprehension. In this group, there is constant backtracking, rereading translated segments, and then moving segments of the translation to produce target syntax where necessary. The excerpt above shows how the same two sentences are treated using this second style. This translator follows the source text structure until a more idiomatic solution is recognized. Then the lexical choice is improved and chunks of text are moved around to reflect target language syntax.

\subsubsection{Monitoring}

Monitoring refers to an awareness of the correctness that accompanies the drafting phase of translation. Several instances of monitoring were observed in this study. It is 
well-documented that most editing takes place as the text segment is produced, as Jensen (2002:111) and Séguinot (1989:34) have observed. The monitoring component that scans previously translated segments seems to be running in the background. For example, in one instance, a subject interrupts the text segment in focus to add the feminine conjugation to 'atteints' in a previous paragraph header. In another instance included below, a second translator becomes aware that patients with ovarian cancer are all women, and she immediately backtracks to the previous paragraph header to correct the spelling of 'patients atteints':

[Excerpt from the transcription of Subject 7]

(21:00) Alors... ce sont...ou est-ce que j'ai écrit ça...les patients...les patients... les patientes atteintes... [adds an " $\mathrm{e}$ " to "patients" and "atteints" in the heading "Aider les patients atteints d'un cancer des ovaires"] ee cancer des ovaires...

Gloss: (21:00) So... they are... where did I write that...the patients...the patients... the patients with... [adds an " $\mathrm{e}$ " to "patients" and "atteints" in the heading "Aider les patients atteints d'un cancer des ovaires"] ee ovarian cancer...

In another excerpt, one subject completes the translation of a sentence and without hesitation, returns to the previous sentence to correct a spelling error. As we can see from these three examples, most cases of monitoring seem to result in spelling corrections rather than more meaningful changes. It is interesting that the computer may have facilitated changes of this kind.

\subsubsection{Online revision}

All nine professionals used online revision to make changes in the drafting phase. The two production styles, prospective thinking and on-screen translating, are also reflected in terms of distinct revision strategies. From the four prospective thinkers subjects who translated mentally and then typed out their translations - most of the changes made during the drafting phase were spelling corrections and the odd change from one translation variant to another. There were many fewer changes in this group overall. On the other hand, the five subjects who translated on-screen made extensive use of online revision to make syntax changes and changes to lexical choice in addition to spelling corrections. In this way the second group makes use of online revision as a shortcut, which gives them the ability to produce text segments quickly and make changes as they go, instead of treating large translation units and reading ahead for meaning. The excerpt below demonstrates how a prospective thinker realizes the subjects must all be women and adds the feminine endings to words that were produced in the masculine:

\begin{tabular}{l|l|} 
[Excerpt from the transcription of Subject 8] \\
(13:15)aider les patientes Aider les pattientses et je vérifierai si on dit
\end{tabular} \begin{tabular}{l}
$\begin{array}{l}\text { Online } \\
\text { revision }\end{array}$ \\
\hline
\end{tabular} (13:15)aider les patientes Aider les pattientses et je verifierai si on dit ovaires...

Gloss: (13:15)Help patients Aider les pattientses and I will verify whether we say atteintses with cancer du cancer of the ovary de l'eovaire or of the ovaries...

This revision can also take the form of more global changes as with heading changes: 
[Excerpt from the transcription of Subject 3]

[Rereading the paragraph heading] (08:38) Alors, aider...alors ça serait améliorer, augmenter, oh c'est moche...aide aux patientes, non j'appellerai ça "cancer des ovaires," c'est moins moche [deletes "Aider les patientes atteintes du c" and adds "C"] Aider les patientes atteintes duc C (09:03) Parce que de toute façon c'est bien que c'est pour une amélioration...donc parle d'un cancer...différent...hmm...en tout cas j'y penserai après...mais je peux suivre l'anglais dans ce cas là

Gloss: [Rereading the paragraph heading] (08:38) Ok, to help... so that would be improve, increase, oh that's no good... help to patients, no I will call this Ovarian cancer, that's not so bad [deletes "Aider les patientes atteintes du c" and adds "C"] Aider les patientes atteintes duc C (09:03) Because in any case it's good that it's for an improvement...so we can change all the titles...Cancer du côlon because each section talks about a different...cancer...hmm... in any case I will think about it later...but I can follow the English in that this case here

\subsubsection{Using internal searching}

Three of the subjects used strategies to facilitate the triggering of appropriate terms. One slotted in the French term:

[Excerpt from the transcription of Subject 1]

Society..uh...would subventionne...uh, it's like sponsor sponsor [Termium Internal SUBVENTIONNER] (01:44) I'm just going to make sure it's sponsor...It's searching like subventionner, like our cafeteria is subventionné what do you call it...

Another remembers having translated 'non-small cell lung carcinoma' previously and uses the previous translation to arrive at 'small cell lung carcinoma.' First the trigger translation is recalled and typed and then it is modified to the target term:

[Excerpt from the transcription of Subject 6]

...j'irai voir dans Termium small cell lung carcinoma et dans MultiTrans aussi parce que ça c'est quelque chose a un des sujets dans lequel on a Internal traduit à cause d'Iressa...est le cancer cancer....non à petites cellules non à petites secellules - non à petites cellules...faut savoir. [Deletes "non"] non

Gloss:...I will look up small cell lung carcinoma in Termium and MultiTrans too because that is one of those things we translate because of Iressa... and cancer cancer...non à petites cellules non à petites secellules - non small cell... have to check. [Deletes "non"] non

\subsubsection{Interference from automatized connections}

Though previously translated segments can be recalled to good advantage, they can also interfere. In three instances, there were false starts caused by interference from previously translated phrases in the text. In these three productions, there are no verbalizations to support an explanation for the change. In fact, the absence of verbalizations makes it all the more likely that a previous chunk has been automatized and recalled accidentally. This exemplifies Séguinot's (1997:117) conclusion that "if direct connections between languages can be learned in the course of a task with repeated patterns, it stands to reason that this same potential underlies what we mean by the expertise that is not available to investigators through think-aloud protocols because 
these automatic responses do not use short-term memory." Séguinot (1997:115) also refers to the finding of Barbara Moser-Mercer, who makes similar conclusions about the interpreting process: "The input for the process is not simply the source language output but the predictions the interpreter can make about future output based on the kinds of elements that have just been discussed." In the excerpt below, it seems that the false start 'a'after 'patientes' is motivated by the repetition of 'patients atteintes' in the previous part of the translation:

[Excerpt from the transcription of Subject 5]

Mats (06:50) Mais, whoop..pas de majuscule is, mais une étude une étude clinique clinique ehm...ehm...une étude clinique qui qui ...regrouper regrouper des patientes acanadiennes et européennes

\begin{tabular}{|l|l|} 
Interference \\
from \\
automatized \\
connection: \\
"patientes \\
atteintes"
\end{tabular}

Gloss: Małs (06:50) But, whoops..no capitalization is, but a une étude clinique clincial study um...um... a clinical study that qui ...regroups regrouper des patientes acanadiennes et européennes

In another subject, the false start "é" after "traitement la plus" may be caused by the repetition of "traitement la plus éfficace" in the previous part of the translation:

\begin{tabular}{l|l|} 
[Excerpt from the transcription of Subject 5] & $\begin{array}{l}\text { Translation style: } \\
\text { Translating On-screen }\end{array}$ \\
\hline (18:19) Cette association médicamenteuse Cette association & $\begin{array}{l}\text { médicamenteuse est maintenant est mainet est devenu devenue } \\
\text { la méthode de traitement la méthơde de traitement la plus }\end{array}$ \\
la plus é utilisé utilisée & $\begin{array}{l}\text { Interence from } \\
\text { automatized connection: } \\
\text { "traitement la plus }\end{array}$ \\
\hline efficace"
\end{tabular}

Gloss: (18:19) This combination of drugs Cette association médicamenteuse has now est mainet become devenue the treatment method la méthode de traitement most la plus é used utilisée

In a third instance, the word 'investigateur'is recalled instead of 'instigateur' because of the graphical connection between the words 'investigateur' and 'instigateur'and because of an automatized connection between the word 'investigateur'and the theme of 'clinical trials.' Séguinot (1997:117) has also identified this type of interference before, and argues that "connections, however, are not necessarily functional; interferences occur all the time between semantically and graphically related words both within and across languages. Some mechanism is required to suppress unwanted connections as well as activate those that are required..." In this case, the subject realizes upon rereading the segment that an unwanted connection has occurred, and corrects it immediately:

[Excerpt from the transcription of Subject 9]

(12:05) Chaque groupe... has led to important changes...(12:08) [mumbles] pas faire de [mumbles]...chaque groupe...je sais quand on est problème, on tourne la phrase d'une façon différente. (12:35) On va

Interference from automatized connection voir qu'est-ce que ça donne...chaque groupe a été l'investigateur... chaque groupe a été l'investigateur d'importants d'importants changements...changfments [inserts " $\mathrm{e}$ " in "changments"] e dans la façon... dans la faàonçon façon dont le cancer... dont le cancer whoops c'est encore en anglais...est traité est traité. [Corrects English autocorrected "don't"] = (13:31) L'investigateur, franchement! [Replaces “investigateur" with “instigateur”] ves s L'instigateur... 
Gloss: (12:05) Each group...has led to important changes...(12:08) [mumbles] not to do [mumbles]...each group...I know that when there is a problem, we turn the phrase in a different way. (12:35) Let's see what this gives us...each group chaque groupe a été l'investigateur... chaque groupe a été l'investigateur d'importants d'importants changements...changfments [inserts " $\mathrm{e}$ " in "changments"] e dans la façon... dans la faàonçon façon dont le cancer... dont le cancer whoops c'est encore en anglais...est traité est traité. [corrects English autocorrected "don't"] = (13:31) Investigator, really! [Replaces "investigateur" with "instigateur"] ses s'instigateur...

\subsubsection{Working unit}

In three instances, three subjects typed a period after translating a proposition and then either erased it or typed over it in order to continue translating to the end of the sentence. The period indicates that the translators in these instances were working at a propositional level and because of constraints on short-term memory, forgot that it was not the end of the sentence. In the example below, we see how a proposition is worked on, revised, and finally, when a satisfactory solution is decided upon, is marked complete with a period.

[Excerpt from the transcription of Subject 4$]$

(02:33) Donc, voici quelques exemples, je lis le paragraphe pour avoir une idée de - bon, ok (02:45) Donc, voici quelques exemples Voici quelques exemples d'essais cliniques d'essais cliniqueques clés clés j’hésite entre clés et principaux je vais mettre clés pour le moment mais peut-être en relisant le texte je vais le changer le mot clé pour le mot principaux ou un autre mot[Rereading] Voici quelques exemples d'essais cliniques...(03:16) Euh...funded ça serait financés financés oui, je pense que c'est le seul - financés...en tout en tout ou en partie ou en partie par la Société par la Société canadienne canadienne $d u$ cancer du cancer. [Period typed after "cancer" marks the subject's perception of a complete sentence]

Period marks translation

Final production: of a proposition, mistaken for a completed sentence

Voici quelques exemples d'essais cliniques clés financés en tout ou en partie par la Société canadienne du cancer par l'intermédiaire du du Groupe des essais cliniques de l'institut national du cancer du Canada.

Gloss: Ok, here are some examples, I read the paragraph to get the idea of - good, ok (02:45) So, here are some examples Voici quelques exemples of key clinical trials d'essais cliniqueques clés I hesitate between "key" and "main" I will put "key" for now but perhaps in rereading the text I will change this word "key" for the work "main" or another word - [Rereading] Here are some examples of key clinical trials...(03:16) Um...funded that will be "financés" financés yes, I think that's the only-funded... completely en tout or in part ou en partie by the Canadian par la Société canadienne cancer Society du cancer. [Period typed after "cancer" suggests the subect's perception of a completed sentence]

The other two instances of this phenomenon occur at the same place in the source text.

\subsection{Shortcuts}

The next sections show that these translators have adapted their process to make use of technology-friendly shortcuts that speed up the drafting phase. These include a shortcut for formatting, mixing source text into the translation, and the use of the highlight- 
ing feature in Microsoft Word as a shortcut to bookmark draft solutions. These general shortcuts are discussed below with examples from the transcribed productions.

\subsubsection{Shortcut for Formatting}

All the subjects used the electronic source text as a template to format their translations. This aspect could only be seen through observing the translation process. It reflects the expectation that translators should provide a translation that is faithful to both the source text content and the source text form. To answer this challenge, the translators typed on top of the source text document pushing the source text segment along until the translation of the segment or several segments was complete, and then deleted them and moved on to the next. The challenge of maintaining the formatting provided some grief for the subjects. Many other difficulties and frustrations using the computer were verbalized during the productions. This is one indication that the demands on the translator have changed. It is safe to say that many areas of translation are facing similar demands to keep up with new programs and stay proficient in computer skills. Although it is beyond the scope of this study, there is some evidence in this subject population to suggest that translators are likely to accumulate numerous coping strategies to fill gaps in technical knowledge, such as this shortcut used for formatting.

\subsubsection{Mixing source text into the translation}

Five of the subjects used a shortcut to translate the term 'Paclitaxel (Taxol).' Instead of simply typing the term into the translation, these subjects erased up to and around the term in the source text, incorporating the source term into the target text and then continuing their translation. It would seem that the tactic of using the source term was less of a disruption to the flow of translating than focusing attention on correctly spelling this obscure term. It is also likely that this is the first time these subjects have translated this particular drug name. Two of the subjects maintained this shortcut throughout the text, integrating source text lexical items to avoid retyping whenever possible. These two subjects have many years of experience in pharmaceutical translation and it seems reasonable to conclude that they have adapted their process to make use of the tools that the word processor provides. An example is given below to illustrate the mixing of source and target texts, and the translation of the term 'Paclitaxel (Taxol)':

[Excerpt from the transcription of Subject 8]

(16:14) Puis là je commence à traduire. Dans lea passée [erases English source text leaving the comma] on a adminsistré le médicament [erases English text leaving "paclitaxel (Taxol)"] aux femmes atteints (16:45) Et puis là je, um, es là je traduit carrément eh, le premier phrase là, comme je Shortcut: disais, sans faire trop de recherche, sans faire aucun recherche en fait. Donc, on a administré le médicament paclitaxel aux femmes atteintes - parce que là j'ai - on avait patientes atteintes du cancer de l'ovaire, donc j'irai la même syntagme aux femmes atteintes du cancer du cancer de l'ovaire de l'ovaire sur une période de (17:20) Ça prend du temps à éliminer [the English source text] une période de 24 heures- ok, oui, [erases English text but leaves "4" and " $\mathrm{h}$ "] 2 eures donc là je fais le premier phrase de ce paragraphe-là. 
Final production:

Dans le passé, on a administré le médicament paclitaxel (Taxol) aux femmes atteintes du cancer de l'ovaire sur une période de 24 heures.

\subsubsection{Draft solutions, highlighting and bookmarks}

Five subjects use draft solutions as placeholders to return to problem terms in revision. Two of the subjects used the highlighting feature in Microsoft Word as a shortcut to mark their draft solutions. The excerpt below illustrates the use of highlighting:

[Excerpt from the transcription of Subject 6]

(07:00) Je continue comme j'ai fait le premier paragraphe Aurapa oop, sauf $\begin{aligned} & \text { Draft } \\ & \text { solution is }\end{aligned}$ que là j'ai pas écrit aupar-auparavant paravant, (07:13) le médicament highlighted Le même chose ici...paclitac- taxel... [erases English text except for the (bookmark) word "paclitaxel"] c'est sur que ça faut faire une recherche donc là je l'ai mis en jaune si on ya mettre ça comme il faut [Returns to previous title to add an " $\mathrm{e}$ " to "atteints" after "patientes"] e était administré aux femmes ataieintes de cancer de l'ovaire padna [began typing "pendant", then decided to type "sur une période" instead] sur une période de 24 heures. [No pause between this and the next sentence]

Final production:

Auparavant, le médicament paclitaxel (Taxol) était administré aux femmes atteintes de cancer de l'ovaire sur une période de 24 heures.

Gloss: (07:00) I am continuing the way I did the first paragraph Aurapa oops, except that there I didn't write aupar-auparavant paravant, (07:13) le médicament The same thing here...paclitac- taxel... [erases English text except for the word "paclitaxel"] this definitely requires research so there, I highlighted it, if we are to do as we should [Returns to previous title to add an "e" to "atteints" after "patientes"] e était administré aux femmes ataieintes de cancer de l'ovaire padra [began typing "pendant," then decided to type "sur une période" instead] sur une période de 24 heures. [No pause between this and the next sentence]

The other subjects only noted verbally: “à réviser" (to be reviewed). Perhaps the lack of more 'bookmarks' in these subjects is due to the fact that they knew they would not in fact reach the revision phase during the 20-minute experiment. The second example demonstrates a verbal bookmark noted in the think-aloud protocol:

[Excerpt from the transcription of Subject 3]

Chaque essais a débouché à des changements [replaces "débouché" with "révolutionné"] débouthé réviolutionné (02:54) "révolutionné" c'est un peu fort mais je trouverai d'autre chose plûtard [replaces "à des changements" with "la façon dont on traite le cancer."] à des changements la façon dont on traite le cancer.

Draft solution is noted in TAP

Final production:

Chaque essai a révolutionné la façon dont on traite le cancer.

Gloss: Chaque essais a débouché à des changements [replaces "débouché" with "révolutionné"] réviolutionné (02:54) "révolutionné" it's a little too strong but I'll find something else later [replaces "à des changements" with "la façon dont on traite le cancer.] à des changements la façon dont on traite le cancer. 


\subsection{Analysing global strategies}

As mentioned previously, the nine professionals in the present study used a combination of strategies and each production has been placed along a continuum between a preference for word count and a preference for a finished product. It is important to note that strategies are not necessarily linked to the translator, but rather the task. The strategies used for this text may not be fixed strategies for the individual subjects. For example, Séguinot (1997:110) studied two translators who worked together and also separately, and found that their strategies differed with each of their translation situations. At the same time, the text represents a routine task for this group of professionals and therefore it is likely that their strategies would not change significantly for other similar tasks. Some of the productions presented signs of two or all three strategies along the continuum while others showed characteristics of one predominant strategy. Despite the patterns and shortcuts described in the sections above and shared by various groups of the subject population, the groupings below are not clear-cut. Instead, what was observed was that each professional had his/her own way of approaching the task, each brought their own knowledge and skills to the task, and each had a different hierarchy of priorities. Given this understanding that groupings are loosely connected at best, the following sections outline what indicators were selected to map the translation productions onto the continuum of strategies that follows. The individual indicators for each subject are listed in Appendix D: Observations by Subject.

FIGURE 3

Model of 9 productions mapped onto a Strategy Continuum

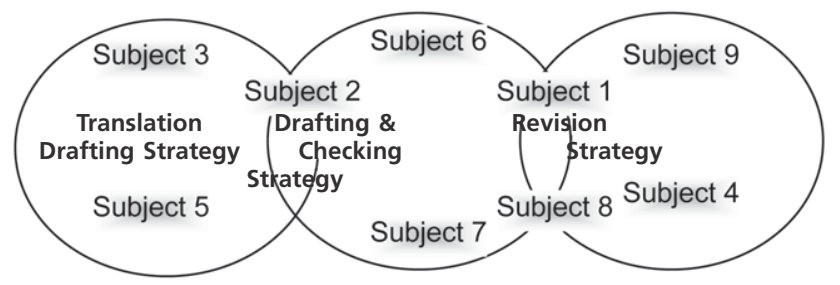

\subsubsection{Translation Drafting Strategy}

The primary objective of the Translation Drafting Strategy is to produce a first draft and revise it later. At this end of the spectrum translators spent very little time verifying their translation choices. The productions using this strategy produced the highest word count and had the lowest research time. Perhaps the motivation behind this strategy comes from the practical explanation given by Séguinot (1999:91): "It may be more productive for translators with word counts to meet to force themselves to produce a preliminary version and then revise it to make sure that it is an adequate translation rather than structure their time to encourage creativity." Some online revision took place during the drafting phase to correct spelling errors or change between translation variants, but most of these changes and decisions occurred within the text segment as it was being produced. These productions move at a steady pace forward, leaving changes to previously translated segments for revision. The think-aloud data also provide many instances where this group of translators noted that a term or expression would require more research later. 


\subsubsection{Drafting and Checking Strategy}

In the middle of the spectrum are the productions that balanced text production and checking references. This group produced a draft with moderate revision, and the use of dictionaries or reference sources. Long interruptions in flow were kept in check by a clear goal to produce a draft and revise it later. This group was more likely to research terms within the text segment being produced and did not move on from a problem without some preliminary research. There seemed to be an unspoken limit on the amount of time spent on a term, before the subject decided to move on and come back to the problem area during a revision phase. Three of these translators highlighted terms that required further research. This group systematically reread the text segment for spelling errors but left some of the changes in meaning to the revision stage.

\subsubsection{Revision Strategy}

At the other end of the spectrum, a third group invested time in getting to the bottom of a problem right away. These productions reflect a goal to complete a revised text. These professionals translated a text segment and then verified their translation with an authoritative source before moving on. This group checked terminology with hardcopy specialized references, and Internet sources to check parallel texts for context, or to compare the frequency of use of one translation variant over another. It is interesting to note that the subjects who used this strategy were all revisers and this role clearly affected their global strategy for this task.

\section{Discussion and conclusion}

Although a number of groupings have been proposed, they do not identify a common methodology among the subjects or the way the text was treated. From the nine professionals, two cognitive styles of production were observed. Three of the translators demonstrated a prospective thinking style identified by large proposition- or sentence-length text segments and a tendency to read ahead for comprehension. These translators solve problems mentally or aloud before they type the solution. They tended to verbalize or mentally translate segments before typing; they posed questions before typing, made template or text-level decisions before typing and dealt with translation problems before typing. Online revision in this group consisted mainly of making changes between translation variants or minor spelling errors while the text segment was in focus.

The other five subjects tended to translate on-screen, which was identified by smaller proposition- or phrase-level text segments. These translators first produced lexical items and phrases that followed the source text closely and then moved the completed text segments around to create a more idiomatic target text. They posed questions after rereading their translation and verbalized as they typed. In this group, syntax changes were often made after typing and translation problems were discovered after rereading. These translators typed as they read and dealt with problems as they arose. Despite the significant differences between these two cognitive approaches to production, they do not provide any basis for the groupings that developed among the shortcuts and strategies. 
There were some findings to suggest that processes have been adapted to use shortcuts introduced by the word processor. Two of the professionals used a method of integrating source text into the translation in order to avoid retyping similar lexical items. In the same way, five of the subjects used this method of mixing source and target text to translate the term 'Paclitaxel (Taxol).' Along the same lines, three of the professionals used the highlighting tool in Word to bookmark terms for the revision stage. Finally, some questions were raised regarding the use of online revision and the fact that translators can make changes without any fear of their process appearing in their final draft. It is possible that this may encourage more changes than we might have seen previous to the computer era.

It was also noted that all of the subjects had developed strategies for managing the formatting requirements that accompany a translation task. The entire subject population used a method of typing on top of the source text and deleting source text segments after translating them. There are more effective formatting solutions available, and the strategy they used caused confusion and frustration in several instances. It would be interesting to look more closely at formatting issues.

In terms of individual patterns, some developed strategies of internal searching to trigger language, and in three instances, what seems to be a memory of previously translated collocations caused false starts.

Rather than homogeneous strategies, this group had a ranging scale of priorities that governed the activities and decisions within the production process. On one side of the scale were translators driven to produce, with the intention of doing research in a revision stage. On the other side of the scale were translators focused on providing a finished product, one text segment at a time. The latter group consisted solely of revisers, whose strategies were likely influenced by their role. A third group of translators shifted between producing text and researching terms. If universal strategies of translation exist, this fairly large, fairly homogeneous group of pharmaceutical translators would have produced them. In their absence, the isolated shortcuts and patterns combined with the range of strategies practised by these nine professionals shows that each translator's process is a unique combination of cognitive style, translating experience, technical skills and world knowledge, which cannot be fit into the static categories we had hoped to find.

\section{REFERENCES}

Ericsson, K. A. \& H. A. Simon (1980): "Verbal Reports as Data," Psychological Review, Vol. 87, p. 215-251.

JäÄSKELÄINEN, R. (1989): “Translation Assignment in Professional vs. Non-Professional Translation: A Think-Aloud Protocol Study," The Translation Process, SÉGuinot, C. (Ed.), New York, H. G. Publications, York University.

Jаковsen, A. L. (2002): "Logging Target Text Production with Translog," Probing the Process in Translation: Methods and Results, Hansen, G. (ed.) Copenhagen Studies in Language 24, Samfundslitteratur, Copenhagen.

Jakobsen, A. L. (2002): "Translation Drafting by Professional Translators and by Translation Students," Probing the Process in Translation: Methods and Results, Hansen, G. (ed.) Copenhagen Studies in Language 24, Samfundslitteratur, Copenhagen.

Jensen, Astrid (1999): “Time Pressure in Translation," Probing the Process in Translation: Methods and Results, Hansen, G. (ed.) Copenhagen Studies in Language 24, Samfundslitteratur, Copenhagen. 
LANGaCKer, R. W. (1987): Foundations of Cognitive Grammar: Theoretical Prerequisites. Stanford, CA: Stanford University Press.

SÉguinot, C. (1988): "Pragmatics and the Explicitation Hypothesis," TTR: Traduction, Terminologie, Rédaction, Vol. 1 (2), p. 106-114.

SÉguinot, C. (1989): “The Translation Process: An Experimental Study," The Translation Process, SÉGuinot, C. (Ed.), New York, H. G. Publications, York University.

SÉGuinot, C. (1997): "Accounting for Variability in Translation," Cognitive Processes in Translation and Interpreting, Thousand Oaks, SAGE Publications.

SÉGuinot, C. (1999): “Translation Theory, Translating Theory and the Sentence," Word, Text, Translation, Liber Amicorum for Peter Newmark, University of Surrey, UK, G. Anderman and M. Rogers (eds.).

Tirkkonen-Condit, S. (1989): "Professional vs. Non-Professional Translation: A Think-Aloud Protocol Study," The Translation Process, C. SÉGuinot (ed.), New York, York University, H. G. Publications.

Toury, G. (1995): Descriptive Translation Studies and Beyond, Amsterdam/Philadelphia: J. Benjamins Pub.

Vinay, J.P. \& J. Darbelnet (1958): Stylistique comparée du français et l'anglais. Paris: Didier.

\section{APPENDIX A - Instructions given to the translator subjects}

Thank you for agreeing to participate in the research study I am conducting to investigate the translation process of professionals.

I will have a workstation set up for you with all the standard reference materials. Feel free to bring along any other resources that you usually use. You can log-on to the computer and access any external resources you wish (i.e. Google, Termium, Le Petit Robert, Grand dictionnaire terminologique). Please do not use any internal resources.

The procedure will be as follows:

- I will show you a demo of how the recording program works and answer any questions you may have.

- Once you are ready to start, please translate as you normally would for 20 minutes. (You do not have to finish the translation.)

- Verbalize your thoughts as much as possible during the translation.

- I will stop the recording when the 20 minutes are up.

- We will print out the translation and discuss the task, process and your background in translation for a maximum of 5 minutes

\section{APPENDIX B - French source text from the French pages of the Canadian Cancer Society website}

\section{Principaux essais cliniques}

Voici quelques-uns des principaux essais cliniques que subventionne en partie ou en totalité la Société canadienne du cancer, par l'entremise du Groupe des essais cliniques de l'Institut national du cancer du Canada. Chacun de ces essais cliniques a contribué à modifier considérablement la manière de traiter le cancer.

À noter: Ces essais sont complets et n'acceptent plus de nouveaux participants.

Des soins mieux adaptés pour les patientes atteintes de cancer des ovaires Autrefois, le paclitaxel (Taxol) était habituellement administré durant une période de 24 heures aux patientes atteintes de cancer des ovaires, jusqu'à ce qu'un essai clinique mené auprès de patientes canadiennes et européennes fasse la preuve qu'il était tout aussi sûr et efficace d'effectuer le traitement en seulement 3 heures. Un essai clinique récent a démontré non seulement que cette nouvelle méthode de chimiothérapie est avantageuse sur le plan du confort, mais qu'elle contribue aussi à retarder la récidive de la maladie et à prolonger la vie de la patiente. 


\section{De meilleurs traitements pour le cancer du côlon}

Une chimiothérapie consécutive à la chirurgie peut, dans certains cas, améliorer de 5 à $10 \%$ le taux de guérison du cancer du côlon. Un essai clinique international a permis d'établir qu'une combinaison de médicaments (incluant de l'acide folinique vitaminique) constituait la forme de chimiothérapie la plus efficace et bénéfique. Cette combinaison particulière sert désormais couramment de base au traitement des patients atteints de cancer du côlon.

Journal of Clinical Oncology, 17(5), 1356-63, 1999

Accroissement du taux de guérison du cancer du poumon

Un type particulier de cancer du poumon, appelé cancer à petites cellules, peut dans certains cas être guéri par des médicaments et des traitements de radiothérapie. Un essai clinique mis sur pied en 1985 a démontré que si les traitements combinés de chimiothérapie et de radiothérapie était administrés suffisamment tôt, on obtenait un taux de guérison de 1 sur 5 (alors que le taux était de 1 sur 10 avec le traitement habituel), si bien que cette approche constitue maintenant la norme thérapeutique en Amérique du Nord.

Journal of Clinical Oncology, 11 (2): 336-344, 1993

\section{Amélioration du traitement contre le cancer du sein}

Les médecins savent bien que si un cancer du sein s'est déjà étendu aux ganglions lymphatiques, il est possible qu'il se soit également propagé ailleurs dans l'organisme. Voilà pourquoi les patientes qui ont subi une intervention chirurgicale au niveau des ganglions sont également traitées ensuite par chimiothérapie. Dans le cadre d’un essai clinique de pointe complété en 1998, les chercheurs ont découvert que l'administration d'un régime médicamenteux comportant une forte dose de pharmorubicine (également appelée épirubicine) avait amélioré le taux de survie et réduit les cas de récidive, comparativement au traitement standard du moment. Cette posologie est désormais couramment utilisée au Canada pour traiter les femmes chez qui on craint une récurrence du cancer du sein.

Journal of Clinical Oncology, 16(8): 2651-8, août 1998

\section{Soulagement des symptômes du cancer du poumon}

Le cancer du poumon, lorsqu'il en est à un stade avancé, peut provoquer des symptômes pénibles comme la toux, l'essoufflement et la douleur thoracique. Pour soulager le patient, on a souvent recours à la radiothérapie, qui sert alors de mesure palliative plutôt que de traitement comme tel de la maladie. Lors d'un essai clinique récent, les chercheurs ont découvert qu'un traitement plus léger sur une plus longue période donnait de meilleurs résultats chez les patients atteins de cancer «non à petites cellules» (la forme la plus courante de cancer pulmonaire). L'essai a permis de déterminer que cinq jours de radiothérapie soulageaient davantage les symptômes qu'une seule dose plus intense de rayonnement. On a également constaté que ce traitement pouvait prolonger la vie des patients de près de deux mois en moyenne. Grâce à cet essai clinique, la plupart des Canadiens atteints de cancer du poumon «non à petites cellules» à un stade avancé reçoivent maintenant cinq traitements de radiothérapie plutôt qu'un.

International Journal of Radiation Oncology, Biology, Physics, 54(3): 719-28, 1er novembre 2002

\section{Contrôle des nausées provoquées par la chimiothérapie}

Les chercheurs travaillent sans relâche à trouver de nouveaux médicaments anticancéreux plus puissants. Par contre, il est important que les patients puissent être capables de tolérer les traitements de chimiothérapie, qui s'accompagnent généralement d'effets secondaires déplaisants, dont les nausées. Une série de neuf études menées de 1982 à 1995 a donné lieu à un nouveau schéma de traitement du cancer destiné à réduire les nausées et les vomissements provoqués par la chimiothérapie. Ces essais ont permis de conclure que la meilleure approche consistait à jumeler l'administration de corticostéroïdes avec celle d'une nouvelle classe de médicaments appelés antagonistes 5HT3. Cette association a pour effet de contrôler les nausées en agissant sur un récepteur du cerveau associé à cette réaction.

Journal of Clinical Oncology, 15 (8): 2966-2973, 1997 
APPENDIX C - English source text from the English pages of the Canadian Cancer Society website

\section{Key clinical trials}

Here are several examples of key clinical trials funded completely or in part by the Canadian Cancer Society through the National Cancer Institute of Canada Clinical Trials Group. Each one has led to important changes in how cancer is treated.

Please note: These trials are completed and are no longer taking patients.

\section{Helping ovarian cancer patients}

In the past, the drug paclitaxel (Taxol) was administered to women with ovarian cancer over a 24hour time period. But a clinical trial involving Canadian and European patients found that the drug was more effective and just as safe when given over a much shorter 3-hour span. A more recent clinical trial has proven that not only is this shorter drug regimen more comfortable and convenient for patients, it actually helps delay the recurrence of ovarian cancer and prolongs the life of women with this disease.

Journal of Clinical Oncology, 12(12), 2654-66, 1994

\section{Improving treatment for colon cancer}

In some cases, giving anti-cancer drugs after colon cancer surgery can improve the cure rate by 5 to $10 \%$. An international clinical trial proved that a combination drug therapy which included the vitamin folic acid was the most effective and beneficial approach. This specific combination of drugs is now the most widely used treatment method for patients with colon cancer.

Journal of Clinical Oncology, 17(5), 1356-63, 1999

\section{Increasing the cure rate for lung cancer}

One specific type of lung cancer called small cell lung carcinoma can sometimes be cured with drugs and radiation. A clinical trial started in 1985 demonstrated that if treatment - a combination of chemotherapy and radiation - was started early enough, 1 in every 5 patients was cured (compared to 1 in every 10 patients who received the then-standard approach.) This treatment for small cell carcinoma of the lung has now become accepted practice throughout North America.

Journal of Clinical Oncology, 11 (2): 336-344, 1993

\section{Improving breast cancer treatment}

When breast cancer spreads to the lymph nodes, doctors know malignant cells may have spread elsewhere in the body. Because of this, surgery in patients with malignant lymph nodes is usually followed by chemotherapy. In a landmark clinical trial completed in 1998, researchers discovered that, compared to standard treatment at the time, an intense drug regimen that included a high dose of a drug called pharmorubicin (also called Epirubucin) improved survival and reduced the rate of cancer recurring. The regimen is now widely used across Canada to treat women whose breast cancer might recur.

Journal of Clinical Oncology, 16(8): 2651-8, August 1998

\section{Relieving lung cancer symptoms?}

In its advanced stages, lung cancer can cause painful symptoms, including coughing, shortness of breath and chest pain. Radiation therapy is often used as a palliative measure to help relieve these symptoms rather than as a way to treat the disease. In a recent clinical trial, researchers found that a longer, milder course of treatment worked best for patients with non-small cell lung cancer (the most common form of lung cancer). The trial found that 5 days of radiation therapy offered more symptom relief than a single, higher dose of radiation. This treatment also extended the patients' life span by almost 2 months on average. Because of this trial, most Canadian patients with advanced non-small cell lung cancer now receive 5 radiation therapy treatments.

International Journal of Radiation Oncology, Biology, Physics, 54(3); 719-28, November 1, 2002 


\section{Controlling nausea associated with chemotherapy}

Researchers continue to search for more powerful anti-cancer drugs. But patients must be able to tolerate chemotherapy, which usually causes unpleasant side effects such as nausea. A series of 9 studies, conducted from 1982 to 1995, established a new treatment practice aimed at reducing the nausea and vomiting caused by cancer treatment. The trials found that the best approach combined corticosteroids with a newer class of drugs called 5HT3 antagonists. These drugs control nausea by acting on a receptor in the brain associated with this symptom.

Journal of Clinical Oncology, 15 (8): 2966-2973, 1997

\section{APPENDIX D - Observations by subject}

Observations by subject

These observations show how each subject is aligned to a production style and the factors that contribute to this conclusion. The general patterns suggest where the production fits on the range of global strategies.

\section{Subject 1}

Patterns related to On-screen translating production style:

- Translating short text segments (proposition or phrase level) (S1) (S9)

- Lexical choice influenced by source text (S1) (S9)

- Online revision: rereading translation and using the word processor to move text segments from source to target syntax (S1) (S2) (S5) (S6) (S7) (S9)

- False start caused by reading ahead and getting ahead of the translation (S1)

- Rereading translation for comprehension (S1) (S2) (S9)

- False starts occur when text segment is too short (backspace during translation or insert words after translation) (S1) (S2)

- Does not read further than current text segment (S1) (S2) (S5) (S9)

- Initial phase: 00:22 minutes

General patterns: Elements of both a Drafting \& Checking and Revision Strategy

- Highlights terms to return to in revision (S1) (S6)

- At decision points, draft solutions serve as placeholders to return to in revision (S1) (S3) (S4) (S6) (S9)

- Monitoring for idiomatic translation (S1) (S2)

- Verbalizes translation variants (S1) (S4)

- Uses internal searching to verify lexical choice and to jog memory (S1) (S6) (S9)

- Total number of reference searches during production: 8

- Total time spent researching: 04:11 minutes

- Total production in 20 minutes: 210 words

\section{Subject 2}

Patterns related to On-screen translating production style:

- Rereading translation for comprehension (S1) (S2) (S9)

- False starts occur when text segment is too short (backspace during translation or insert words after translation) (S1) (S2)

- Verifying translation for meaning is left to revision stage (S2)

- Variable length of text segments (S2)

- Does not read further than current text segment (S1) (S2) (S5) (S9)

- Initial phase: 00:12 minutes

General patterns: Elements of both a Drafting and Drafting \& Checking Strategy

- Types draft translation solution, then looks it up (S2)

- End of a text segment is marked by a self-motivational comment in the TAP (S2) (S5) (S7) (S9)

- Translating several segments together, then rereading for errors (S2)

- Online revision: rereading translation and using the word processor to move text segments from source to target syntax (S1) (S2) (S5) (S6) (S7) (S9) 
- Monitoring for idiomatic translation (S1) (S2)

- Corrects spelling errors after completing a text segment (S2) (S7)

- Total number of reference searches during production: 9

- Total time spent researching: 03:23 minutes

- Total production in 20 minutes: 218 words

\section{Subject 3}

Patterns related to Prospective thinking production style:

- Reads large source segment for full comprehension (S3) (S4) (S8)

- Translates long or sentence-length text segments (S3)

- Text-level questions suggest the translator is creating a template, a uniform translation which conforms to its own rules (S3) (S4) (S6)

- Translates orally or mentally before beginning to type, typed translation is usually final (S3) (S4) (S8)

- Initial phase: 01:02 minutes

- Scanned whole text before beginning

- Online revision primarily for spelling corrections and changes between translation variants (S3)

General patterns: Elements of a Drafting Strategy

- Breaks occur at decision points (S3) (S4)

- At decision points, draft solutions serve as placeholders to return to in revision (S1) (S3) (S4) (S6) (S9)

- Minimal typing errors (S3)

- Break in flow due to the fact that the subject is working through a previously encountered problem (S3) (S9)

- Total number of reference searches during production: 0

- Total time spent researching: 0 minutes

- Total production in 20 minutes: 347 words

\section{Subject 4}

Patterns related to Prospective thinking production style:

- Reads large source segment for full comprehension (S3) (S4) (S8)

- Translates orally or mentally before beginning to type, typed translation is usually final (S3) (S4) (S8)

- Text-level questions suggest the translator is creating a template, a uniform translation which conforms to its own rules (S3) (S4) (S6)

- Initial phase: 02:00 minutes

- Scanned whole text before beginning

- Online revision primarily for spelling corrections and changes between translation variants (S3)

- Half-way through, decides to translate all the section headers in order to get a better understanding of the text

General patterns: Elements of a Revision Strategy

- Breaks occur at decision points (S3) (S4)

- Typed a period after translating a proposition, mistaken for a full sentence phrase (S4) (S5) (S6)

- Distracted by technical difficulties (S4)

- At decision points, draft solutions serve as placeholders to return to in revision (S1) (S3) (S4) (S6) (S9)

- Monitoring translation for typing errors (S4) (S6) (S7) (S8)

- Rereads translation at the end of a paragraph (S4)

- Verbalizes translation variants (S1) (S4)

- The term Paclitaxel (Taxol) was not typed; the subject erased up to and around this term directly from the source text (S4) (S6) (S7) (S8) (S9)

- Uses the number of hits on Google to help decide between translation variants (S4) (S8) (S9)

- Total number of reference searches during production: 4

- Total time spent researching: 03:30 minutes

- Total production in 20 minutes: 105 words 


\section{Subject 5}

Patterns related to On-screen translating production style:

- Reads aloud the whole text segment while translating it (S5)

- Types and thinks aloud simultaneously (S5)

- Online revision: rereading translation and using the word processor to move text segments from source to target syntax (S1) (S2) (S5) (S6) (S7) (S9)

- Does not read further than current text segment (S1) (S2) (S5) (S9)

- Mixing source text into the translation, instead of typing similar text in French, by erasing around unwanted source text (S5) (S8)

- Initial phase: 00:18 minutes

General patterns: Elements of a Drafting Strategy

- Encounters formatting difficulties (S5)

- End of a text segment is marked by a self-motivational comment in the TAP (S2) (S5) (S7) (S9)

- The term Paclitaxel (Taxol) was not typed; the subject erased up to and around this term directly from the source text (S4) (S6) (S7) (S8) (S9)

- Typed a period after translating a proposition, mistaken for a full sentence phrase (S4) (S5) (S6)

- Correcting a typing error leads subject to revise a lexical choice (S5)

- Revises previous unit before moving on (S5) (S9)

- Interference from automatized connections from previously translated phrases in the text (S5) (S8) (S9)

- Total number of reference searches during production: 1

- Total time spent researching: 00:40 minutes

- Total production in 20 minutes: 278 words

\section{Subject 6}

Patterns related to On-screen translating production style:

- Translation and TAP occur consecutively (S6) (S8)

- Online revision: rereading translation and using the word processor to move text segments from source to target syntax (S1) (S2) (S5) (S6) (S7) (S9)

- Initial phase: 00:37 minutes

\section{General patterns: Elements of a Drafting \& Checking Strategy}

- The term Paclitaxel (Taxol) was not typed; the subject erased up to and around this term directly from the source text (S4) (S5) (S6) (S7) (S8) (S9)

- Relies on autocorrect to capitalize words at the beginning of a sentence (S6)

- Text-level questions suggest the translator is creating a template, a uniform translation which conforms to its own rules (S3) (S4) (S6)

- Monitoring translation for typing errors (S4) (S6) (S7) (S8)

- Typed a period after translating a proposition, mistaken for a full sentence phrase (S4) (S5) (S6)

- Uses internal searching to verify lexical choice and to jog memory (S1) (S6) (S9)

- Highlights terms to return to in revision (S1) (S6)

- At decision points, draft solutions serve as placeholders to return to in revision (S1) (S3) (S4) (S6) (S9)

- Total number of reference searches during production: 4

- Total time spent researching: 01:18 minutes

- Total production in 20 minutes: 240 words

Note: Subject usually begins by scanning source text with MultiTrans to determine previously translated expressions and terms. Secondly, subject uses web resources i.e. Google and Termium for other preliminary researches. A back-up approach is used in this production, because MultiTrans is excluded from the study and web resources are not available due to technical difficulties (S6) 


\section{Subject 7}

Patterns related to On-screen translating production style:

- Online revision: rereading translation and using the word processor to move text segments from source to target syntax (S1) (S2) (S5) (S6) (S7) (S9)

- Initial phase: 00:20 minutes

General patterns: Elements of a Drafting \& Checking Strategy

- Keyboard problems significantly interrupt workflow (S7)

- The term Paclitaxel (Taxol) was not typed; the subject erased up to and around this term directly from the source text (S4) (S5) (S6) (S7) (S8) (S9)

- Corrects spelling errors after completing a text segment (S2) (S7)

- During some translations, TAP consists of conjunctions only (S7)

- End of a translation unit is marked by a self-motivational comment in the TAP (S2) (S5) (S7) (S9)

- Monitoring translation for typing errors (S4) (S6) (S7) (S8)

- When cut and paste does not work, and a term does not copy properly into the document, the subject has to return to the reference in order to recall the translation (S7) (S8)

- Total number of reference searches during production: 5

- Total time spent researching: 03:09 minutes

- Total production in 20 minutes: 234 words

\section{Subject 8}

Patterns related to Prospective thinking production style:

- Reads large source segment for full comprehension (S3) (S4) (S8)

- Translates orally or mentally before beginning to type, typed translation is usually final (S3) (S4) (S8)

- Translation and TAP occur consecutively (S6) (S8)

- Initial phase: 01:19 minutes

General patterns: Elements of a Revision Strategy

- The term Paclitaxel (Taxol) was not typed; the subject erased up to and around this term directly from the source text (S4) (S5) (S6) (S7) (S8) (S9)

- Copies and pastes source text into search fields and copies and pastes researched translations into target text (S8)

- Mixing source text into the translation, instead of typing similar text in French, by erasing around unwanted source text (S5) (S8)

- Monitoring translation for typing errors (S4) (S6) (S7) (S8)

- When cut and paste does not work, and a term does not copy properly into the document, the subject has to return to the reference in order to remember the translation (S7) (S8)

- Interference from automatized connections from previously translated phrases in the text (S5) (S8) (S9)

- Uses the number of hits on Google to help decide between translation variants (S4) (S8) (S9)

- Researches and translates terms and then "fills in" the rest of the text segment translation

- Total number of reference searches during production: 7

- Total time spent researching: 05:03 minutes

- Total production in 20 minutes: 126 words

\section{Subject 9}

- Patterns related to On-screen translating production style:

- Translating short text segments (proposition or phrase level) (S1) (S9)

- Rereading translation for comprehension (S1) (S2) (S9)

- Lexical choice influenced by source text (S1) (S9)

- Does not read further than current text segment (S1) (S2) (S5) (S9)

- Online revision: rereading translation and using the word processor to move text segments from source to target syntax (S1) (S2) (S5) (S6) (S7) (S9) 
General patterns: Elements of a Revision Strategy

- Translate a text segment then verifies with an authoritative source before moving on

- Uses the number of hits on Google to help decide between translation variants (S4) (S8) (S9)

- Uses internal searching to verify lexical choice and to jog memory (S1) (S6) (S9)

- The term Paclitaxel (Taxol) was not typed; the subject erased up to and around this term directly from the source text (S4) (S5) (S6) (S7) (S8) (S9)

- Break in flow due to the fact that the subject is working through a previously encountered problem (S3) (S9)

- Revises previous text segment before moving on (S5) (S9)

- End of a translation unit is marked by a self-motivational comment in the TAP (S2) (S5) (S7) (S9)

- At decision points, draft solutions serve as placeholders to return to in revision (S1) (S3) (S4) (S6) (S9)

- Interference from automatized connections from previously translated phrases in the text (S5) (S8) (S9)

- Initial phase: 01:32 minutes

- Total number of reference searches during production: 15

- Total time spent researching: 10:35 minutes

- Total production in 20 minutes: 72 words 